\title{
The OECD again: legitimization of a new vocationalism in the educational policies in Portugal (1979-1993)
}

\section{António Teodoro \& Teresa Teixeira Lopo}

To cite this article: António Teodoro \& Teresa Teixeira Lopo (2021): The OECD again: legitimization of a new vocationalism in the educational policies in Portugal (1979-1993), Paedagogica Historica, DOI: 10.1080/00309230.2021.1941143

To link to this article: https://doi.org/10.1080/00309230.2021.1941143

曲 Published online: 30 Jun 2021.

Submit your article to this journal

View related articles $₫$

View Crossmark data $\widetilde{\nearrow}$ 


\title{
The OECD again: legitimization of a new vocationalism in the educational policies in Portugal (1979-1993)
}

\author{
António Teodoro (iD) and Teresa Teixeira Lopo (D) \\ CeiED - Interdisciplinary Research Centre for Education and Development, Lusófona University, Lisbon, \\ Portugal
}

\begin{abstract}
This paper presents an analysis of the examination of Portugal's education policy conducted by the Organization for Economic Cooperation and Development (OECD) in 1987 as well as of its role in the legitimation of a new vocationalism. In particular, the focus is on the key recommendation put forward in the examiners' report regarding the investment in the initial professional qualification of young people and its relation with the creation, in 1988, of a new administrative body within the Portuguese Ministry of Education tasked with coordinating the system of non-higher education in the area of technological, artistic and professional education, responsible for launching the professional schools in 1989, and also the technology courses at secondary-school level in 1993. The results of our analysis suggest that it was this examination by the OECD that effectively paved the way for the renascence of professional education in Portugal, but now rethought and redefined as a socially regulated, extended and grounded form of vocationalism.
\end{abstract}

\section{ARTICLE HISTORY}

Received 19 May 2020

Accepted 28 May 2021

\section{KEYWORDS}

Portugal; education policies; OECD; new vocationalism

\section{Introduction}

In this article we analyse the examination of Portugal's education policy conducted in 1987 by an international intergovernmental entity, the Organization for Economic Cooperation and Development (OECD), as well as its role in the legitimation of a new vocationalism in education policies. In fact, the emergence of a vast system of organisations of this type - besides the United Nations itself, other specialised organisations like UNESCO in the area of education, science and culture, or the International Monetary Fund (IMF) and the World Bank, in finance and development support, and regarding economic cooperation the OECD - has given great encouragement to the internationalisation of education problems. Devising education policies, particularly in peripheral (or semi-peripheral) countries, increasingly depends on the legitimatisation and technical support of international organisations (IOs). The effort to establish a scientific rationality has permitted the formulation of general laws able to guide the reforming action in the education of each country - conferences, surveys, studies - conducted by all those IOs. This, in turn, has enabled the creation of several networks of contact, funding and 
exchange of information and knowledge among national political-administrative authorities, social actors, experts and researchers.

The development of these networks relied on the concept of comparative education, centred, according to António Nóvoa, ${ }^{1}$ on four essential pillars: the ideology of progress, a concept of science, the concept of the nation-state, and the definition of a comparative methodology. The first issue, the ideology of progress, is manifest in the assumption that education is equal to development, that is, the idea that the expansion and improvement of education systems undoubtedly secure socioeconomic development. The second aspect, a concept of science, is built on the positivist paradigm of social sciences developed from the second half of the nineteenth century, which accords science - in this case comparative education - the role of establishing general laws on the functioning of educational systems, thus legitimising the rhetoric on the efficiency of education policies, considered the core of all reforming action. The third anchor, the concept of the nationstate, derives from the vision of the nation as a privileged community of analysis, which in general leads to studies stressing the differences and similarities between two or more countries. The last aspect, the definition of a comparative methodology, acquires its main dimension in the rhetoric of objectivity and quantification, which poses the problem of gathering and reviewing data but rarely addresses one other problem, the very construction of data and of the theoretical framework underlying them.

Comparative education, perhaps due to its origins, has served as a means for national authorities to legitimise their policies. From this perspective, resorting to solutions from abroad primarily worked as an element of legitimisation of the political options taken at national level. Thus, an instrumental positivism prevails which would shape comparative research into an epistemological fallacy, in the sense that resorting to what is foreign works primarily as a way of legitimising options assumed in the national sphere and has very little to do with a serious effort to acquire contextualised knowledge on other experiences and realities. ${ }^{2}$ Conversely, however, constant surveys and publications by IOs can be considered to play a decisive role in regulating national educational policies, by setting an agenda defining not only the priorities, but also how problems should be equated and solved, which constitutes the establishment of a more or less explicit mandate, diffuse but present, responsible for the semantic construction of world society. ${ }^{3}$

The relationship between national educational policies and initiatives of technical assistance on the part of IOs, which simultaneously assumed the character of legitimisation and mandate, had different protagonists in the period from the end of the Second World War to 1 January 1986, when Portugal joined the European Economic Community/European Union (EEC/EU). In fact, privileged relationships with various IOs with intervention in the educational area can be located in that period: first, with the

\footnotetext{
${ }^{1}$ António Nóvoa, "Modèles d'analyse en éducation comparée: Le champ et la carte [Models of analysis in comparative education: The field and the map]," Les sciences de l'éducation: Pour l'ère nouvellle no. 2-3 (1995): 9-61.

${ }^{2}$ Thomas S. Popkewitz, and Miguel A Pereyra, "Estudio Comparado de las Prácticas Contemporáneas de Reforma de la Formación del Profesorado en Ocho Países: Configuración de la Problemática y Construcción de una Metodología Comparativa [Comparative Study of the Contemporary Reform Practices in Teacher Education in Eight Countries: Configuration of the Problem and Design of a Comparative Methodology]," in Modelos de Poder y Regulación Social en Pedagogia. Crítica Comparada de las Reformas Contemporáneas de la Formación del Professorado, ed. T. S. Popkewitz (Barcelona: Pomares-Corredor, 1994).

${ }^{3}$ Jurgen Schriewer, "L'éducation Comparée: Mise en Perspective Historique d'un Champ de Recherche [Comparative Education: Historical Perspective of a Field of Research]," Révue Française de Pédagogie no. 4 (1997): 9-27.
} 
OECD, until 1974, a relationship we discussed in detail in a previous article; ${ }^{4}$ then with UNESCO, in the revolutionary crisis period of 1974-1975; after the normalisation of the revolution, from 1976 to 1978, with the World Bank; and finally, again with the OECD, in two consecutive periods: the times immediately before and after Portugal joined the $\mathrm{EEC} / \mathrm{EU}$.

Let us recall that the OECD was created in 1961, following the Organization for European Economic Co-operation (OEEC), founded in 1948 with the goal of distributing the help promised by the Marshall Plan and of fostering economic cooperation among its member countries, but at the same articulating political and economic purposes. Indeed, in light of the tense relations between East and West during the Cold War, the OEEC played an explicitly political role, becoming the main international institution engaged in the defence and development of free-market policies. ${ }^{5}$

The OEEC was then constituted by 18 member countries. Portugal was one of the founding countries and also integrated the more restricted executive committee, together with France, Greece, Holland, the United Kingdom, Italy and Norway. On 14 December 1960, OEEC members signed with the United States of America and Canada a new Convention, ${ }^{6}$ which came into force on 3 September 1961, a date which formally marks the foundation of the OECD. Just as in the relation with its predecessor, each country's affiliation would be bound to the commitment with the development of a market economy.

As Centeno remarked, the OECD "was designed as a place (...) where like-minded countries could build a common economic but also cognitive transnational space (...) that moved from being territorially centred to become conceptually centred". Additionally, vis-à-vis the OEEC, which was able to issue binding decisions, the OECD was equipped with weaker legal instruments. ${ }^{8}$ Regarding its goals, there is no explicit reference to education in the OECD Convention though "there was always an inferred role', derived from early human capital formulations of links between economic productivity and educational investment". ${ }^{9}$ Besides, as Papadopoulos observed, "the nearest it comes to getting such a reference is in Article 2(b), on policies designed to promote the development of Member countries' resources, in science and technology, to encourage research and to promote vocational training". ${ }^{10}$

For the analysis of the examination conducted by the OECD on Portugal's education policy as well as of its role in the legitimation of a new vocationalism in education policies in Portugal, the core topic of this paper, we used open-access official sources and public sources, a collection which comprised primary and secondary sources, primarily

\footnotetext{
${ }^{4}$ António Teodoro, "The end of isolationism: examining the OECD influence in Portuguese education policies, 1955-1974," Paedagogica Historica 56, no. 4 (2020): 535-47. DOI: https://doi.org/10.1080/00309230.2019.1606022.

${ }^{5}$ Svein Sjøberg, "The PISA-syndrome - How the OECD has Hijacked the Way We Perceive Pupils, Schools and Education," Confero 7, no. 1 (2019).

${ }^{6}$ The full text of the Convention may be accessed at: https://www.oecd.org/general/conventionontheorganisationforeco nomicco-operationanddevelopment.htm.

${ }^{7}$ Vera G. Centeno, The OECD's Educational Agendas - Framed from Above, Fed from Below, Determined in Interaction. A Study on the Recurrent Education Agenda (New York: Peter Lang, 2017), 28.

${ }^{8}$ Kerstin Martens and Anja P. Jakobi, "Introduction: The OECD as an Actor in International Politics," in Mechanisms of OECD Governance: International Incentives for National Policy-Making?, ed. K. Martens and A. P. Jakobi (Oxford: Oxford University Press, 2010), 1-25.

${ }^{9}$ Fazal Rizvi and Bob Lingard, "The OECD and Global Shifts in Education Policy," in International Handbook of Comparative Education, ed. R. Cowen and A. M. Kazamias (Dordrecht: Springer, 2009), 438.

${ }^{10}$ George Papadopoulos, Education 1960-1990: The OECD Perspective (Paris: OECD, 1994), 11.
} 
documents in Portuguese, including, reports, legal documents and statistical data, followed by a selection of literature consisting of publications in Portuguese, English and French. To ensure the quality of this collection, the criteria of external evaluation of authenticity, credibility and representativeness of the collected documents were established, ${ }^{11}$ as well as of their pertinence and relevance to the knowledge we aimed to build.

From a formal viewpoint, the paper is divided into four sections. Firstly, we will briefly present the 1973 Education Reform (and the sources of Portuguese educational backwardness), which constituted a turning point in the Portuguese education policy while acting as lever of the debates about the future, particularly those about the country's economic development and modernisation. In the second section, we will address the return of the OECD, in the 1980s, to a dominant role in national politics, with the examination of the Portuguese education policy and its impact in the definition of a national emergency plan for technical-vocational education. The third section focuses on the emergence, in the 1990s, of a school-based model containing elements of an extended and grounded vocationalism. The article closes with a final remark.

\section{Before the OECD's comeback: the sources of Portuguese educational backwardness and the educational reform of 1973}

In the mid-nineteenth century, the European countries were divided into, at least, two groups, depending on their population's levels of literacy and schooling. In the first group were the north-European countries, wealthier and more industrialised, predominantly (but not exclusively) Protestant, where literacy had been developed in the eighteenth century or even earlier. The second group was constituted by the countries from southern and eastern Europe, poor and more rural in nature, predominantly Catholic or Orthodox, whose populations presented high rates of illiteracy.

While other countries in southern Europe, such as Spain, Italy or even Greece, made significant advances in the literacy levels of their populations at the beginning of the twentieth century, Portugal's distance from other European countries expanded. ${ }^{12}$ Despite the regeneration resolutions of the successive liberal elites, in the nineteenth century Portugal saw its backwardness increase vis-à-vis the central European countries as regards the modernisation of the economic and social structures.

Notwithstanding the generous intentions of the liberal Republic (1910-1926), ${ }^{13}$ at the end the first quarter of the twentieth century it was still not possible to speak of mass schooling in Portugal. Primary school covered only about one-third of school-age children, secondary education as well as technical, industrial and commercial education, collectively, taught no more than 5 to $7 \%$ of the school-age population, while the three

\footnotetext{
${ }^{11}$ W. Robinson, "Documentary research," in Educational Research and Inquiry: Qualitative and Quantitative Approaches, ed. D. Hartas (London: Bloomsbury, 2010).

${ }^{12}$ See, among others, the very interesting comparative effort of António Candeias, "Literacy, Schooling and Modernity in the Twentieth Century Portugal: What Population Censuses Can Tell Us," Paedagogica Historica 40, no. 4 (2004): 509-30. DOI: https://doi.org/10.1080/0030923042000250027.

${ }^{13}$ The characterisation is by António Nóvoa, "A República e a Escola: das intenções generosas ao desengano das realidades," in Reformas do Ensino em Portugal Reforma de 1911. Tomo II, vol. 1 (Lisbon: Ministério da Educação / Instituto de Inovação Educacional, 1989), IX-XXIV.
} 
universities in the country were attended by a little over 4,000 students. ${ }^{14}$ The 1930 census showed that only $38 \%$ of the population over 7 years of age were literate. ${ }^{15}$

It would be only in the 1960s that Portugal would begin a process of renegotiation of its integration in the world system. In spite of the resistances of Salazarism, ${ }^{16}$ the Portuguese society of the post-Second World War period gradually underwent a set of invisible changes ${ }^{17}$ in the areas of demography, territorial reorganisation and the structure of the active population, which would quickly change its face. The turning years of education policy can be found in the 1950s, with the implementation of the reform of technical education and the Popular Education Plan, and in the 1960s, with the participation in the Mediterranean Regional Project. ${ }^{18}$ Nonetheless, it would be at the beginning of the 1970s that education would take centre stage in the process of re-composition of the State and in the debates on the modernisation and the development of the country.

In fact, in the early 1970s, a reform project emerged in Portugal, whose repercussions, especially if we bear in mind that at the time the regime was a dictatorship, have far surpassed the boundaries of the educational system. ${ }^{19}$ The Minister of National Education, Veiga Simão, in his inaugural speech in January 1970, remarked about the future of the nation that:

Definitely ... it does not lie only in closed, small elites. The reduced aristocracies of culture have to be opposed to the education of the masses, constant concern of the rulers of today, which we would even have to embrace as an imperative of national survival. That nostalgia of the past ... has to be opposed to the democratisation of teaching in extension and depth, a primordial factor of the country's progress. ${ }^{20}$

One year later, Veiga Simão presented on the national television the key documents of an ambitious educational reform: The School System Project and the General Guidelines for the Reform of Higher Education, calling for a broad participation in their public discussion. As Stephen Stoer noted, ${ }^{21}$ those documents attracted the attention of all Portuguese, becoming, at least in some aspects, the crux of sociopolitical life insofar as they embodied long-felt aspirations and needs, whose satisfaction, however, had been constantly postponed.

In 1973, Law no. 5/73, of 25 July, approved the bases of the reform of the Portuguese educational system, putting an end to the traditional divisions between technical and professional education and grammar schools. It established the State's duty to guarantee everyone's right to education "through the access to the various levels of education and

\footnotetext{
${ }^{14}$ See António Teodoro, A Construção Política da Educação. Estado, Políticas Educativas e Mudança Social no Portugal Contemporâneo [The Political Construction of Education. State, Social Change and Educational Policies in Contemporary Portugal] (Porto: Edições Afrontamento, 2001), 61-172.

${ }^{15}$ António Candeias, see reference at footnote 12.

${ }^{16}$ Expression generically given to the period of the Estado Novo Dictatorship, associated to António de Oliveira Salazar, which occupied the leadership of the government between 1933 and his physical incapacitation in 1968.

${ }^{17}$ The expression was coined by Fernando Rosas, "O Estado Novo (1926-1974)," in História de Portugal, Vol. VII, dir. J. Mattoso (Lisbon: Círculo de Leitores, 1994).

${ }^{18}$ António Teodoro (2020), see reference at footnote 4.

${ }^{19}$ Stephen R. Stoer, "A reforma de Veiga Simão no ensino: Projecto de desenvolvimento social ou "disfarce humanista? [Veiga Simão's reform in education: Social development project or "humanist disguise"?]" Análise Social 19, no. 77-78-79 (1983): 793-822.

${ }^{20}$ José Veiga Simão, A Batalha da Educação [The Battle of Education] (Lisbon: Ministério da Educação Nacional, 1970).

${ }^{21}$ Stephen R. Stoer, reference at footnote 19.
} 
cultural goods, with no distinction other than that resulting from the capacity and merits of each individual". 22

Even though this reform would not be fully enforced due to the Carnation Revolution in 1974, it promoted a turning point in education policy, in the shape of popular resistance, as opposed to political exclusion and technocratic determination, and worked as a pivot to debates about the future, especially in such areas as economic development and the modernisation of the country, thus creating space and a platform for new forms and subjects of discussion and of educational practice. Still according to Stoer, the democratic school reappeared in Portugal with the social and cultural mobilisation developed in the revolutionary period. ${ }^{23}$ Measures taken in the field of education, including the extinction of technical education, ${ }^{24}$ in June 1975 , should be regarded as attempts to reverse the role of the school in the reproduction of social inequalities that are inscribed in the development of a model of democratic school that is able to express concerns about the establishment of a critical relationship between the school and the world of production.

\section{The OECD's examination of 1983 and its impact: the Portuguese government's emergency plan for technical-vocational education}

The return of the OECD to a dominant role in national education would take place at the beginning of the 1980s, after the decision of the Portuguese government ${ }^{25}$ to apply for its integration to in the group of OECD countries participating in the programme examination of national educational policies. The intention was to use this examination as a preliminary study for the groundwork leading to the preparation of the desired Comprehensive Law on the Education System, ${ }^{26}$ a sort of external audit to the educational situation, complementary to another observation and reflection exercise resulting

\footnotetext{
${ }^{22}$ Governo de Portugal. Diário do Governo, I Série, n. ${ }^{\circ} 173,1973,1315$.

${ }^{23}$ Stephen R. Stoer, reference at footnote 19.

${ }^{24}$ Nevertheless, the first attempt to reintroduce vocational education in the educational system started in 1978, when guidelines were adopted by ministerial order aimed at the introduction of vocational components in the 10th and 11 th grades. The measure had, however, minor consequences for the evolution of the system, and then another change took place in 1980, upon the creation of the 12th grade. Two streams were made available, a general and a vocational one. The latter seems to have resulted in a relative failure, because there had been promises of entry into active life and access to higher education that had not been fulfilled. According to Cardim, despite the repeated reference to the extinction of technical education, the old technical courses of Veiga Simão's Reform, in the format of evening classes, were maintained and, also in 1983, they registered some thousands of students, with about 20 courses running (José C. Ministério da Educação, Relatório e Documentos do Encontro para Apresentação Pública do Exame da Política Educativa da OCDE [Report and Documents of the Meeting for the Public Presentation of the OECD Educational Policy Exam] (Lisbon: Gabinete de Estudos e Planeamento, 1984). [From Industrial Education to Vocational Training. Public Policies in Portugal], PhD Thesis (not published), ISCSP-Universidade Técnica de Lisboa, Lisbon, 2005).

${ }^{25}$ The Government was led by Maria de Lourdes Pintasilgo (July 1979 - January 1980), the first (and, so far, only) woman Prime Minister in Portugal. The Minister of Education was Luís Veiga da Cunha, a specialist in the environment and natural resources, with strong ties to IOs.

${ }^{26}$ The Portuguese Revolution of April 1974 (and the revolutionary process that followed it) generated a complex power problem. Once this issue was overcome, with the approval of the new Constitution in 1976, the normalisation of the educational field would take place under a new mandate, the European challenge, which materialised in a long period of time between the swearing in of the government coming out of the elections in 1976, and the approval of the Comprehensive Law on the Education System in 1986, also the year of Portugal's entry into the EEC/EU. For the development of this argument see Teodoro, A Construção Política da Educação. Estado, mudança social e políticas educativas no Portugal contemporâneo, 387-415.
} 
from piecemeal contributions by a group of Portuguese experts related to the situation and from perspectives of the educational system. ${ }^{27}$

The exam conducted by OECD experts in the early 1980s took the same format as the examinations that had been carried out by the OECD in other countries, such as Greece, Finland or New Zealand. ${ }^{28}$ Henri Gauthier, a member of the team that examined Portugal, considered those examinations "a traditional OECD activity ... in the double sense of, on the one hand, better knowing the respective systems and making them known, and on the other hand thus bringing together rich documentation that allows for international comparisons". ${ }^{29}$

The Portuguese examination included a report by a Portuguese team containing an analysis of the evolution of the education policy and the education system from 1974 to 1982, and a set of proposals in the areas of educational administration, school access and progression, school network, school construction and equipment, educational innovation and teacher training, school management and adult education. The document also integrated the results gathered by the visit of the OECD's team of examiners, which took place in 1982, including interviews with the authors of the national report, policy-makers, managers, technicians, teachers and other relevant actors in the national education policy. This report was drawn up by the examiners following an examination interview, held in Paris in 1983, with a team from the Ministry of Education. ${ }^{30}$

The final report, published in 1983, contained an introduction which dealt with the external factors impacting on the Portuguese educational system, namely the consequences of the 1974 political coup, the economic difficulties, the imminent accession to the EEC/EU and the growing expectations of public opinion on education. This was followed by five autonomous chapters devoted, respectively, to the definition and administration of education policy, structuring of the education system, vocational and technical education, specific school issues (e.g. private education, teacher absenteeism) and higher education (the shortest chapter).

The OECD report published on 6 May 1983, examining education policy in Portugal, advocated the strengthening of vocational education, and stated that the obvious priority was "to establish a technical education system practically from scratch", that the intention of this education system was to "train the intermediate technicians the country needs", 31 and that "technical and vocational education should be a top priority in educational policy". ${ }^{32}$ At the meeting organised for the public disclosure and debate of the report produced by the OECD, held in Lisbon on 16 and 17 July 1984, "two issues

\footnotetext{
${ }^{27}$ This work was later published, after the end of the government mandate, in an edition of the Gulbenkian Foundation: Manuela Silva and Isabel Tamen, eds., Sistema de Ensino em Portugal [Education System in Portugal] (Lisbon: Fundação Calouste Gulbenkian, 1981).

${ }^{28}$ At the OECD meeting held in Lisbon on 16 and 17 July 1984, Henri Gauthier, a member of the team that examined Portugal, said that until that date 17 countries had already taken this exam, some of which for the second time (Ministério da Educação, Relatório e Documentos do Encontro para Apresentação Pública do Exame da Política Educativa da $O C D E)$.

${ }^{29}$ Ministério da Educação, Relatório e Documentos do Encontro para Apresentação Pública do Exame da Política Educativa da OCDE, 31.

${ }^{30}$ The team was headed by the Minister of Education, João Fraústo da Silva (replaced in the position by José Augusto Seabra on the same day the interview was held) and included, among others, the Secretary of State of Education João de Deus Pinheiro and the Coordinator of the National Report, Manuel Tavares Emídio.

${ }^{31} \mathrm{OCDE}$, Exame das Politicas Nacionais de Educação: Portugal [Examination of National Policies on Education: Portugal] (Lisbon: Gabinete de Estudos e Planeamento, 1984), 78.

${ }^{32} \mathrm{OCDE}$, Exame das Políticas Nacionais de Educação, 88.
} 
were isolated because of their importance in our education system and because of their relevance in the report of the OECD examiners". ${ }^{33}$

On the above-mentioned choice of the subject of vocational and technical education, Henri Gauthier stated that it remained a key problem, one of the conditions of the country's economic development, adding that "this aspect has indeed seemed to us an element that should be the subject of reflection and immediate solutions". ${ }^{34}$

In the same meeting, the new Minister of Education, José Augusto Seabra, stressed the importance of confronting, in the proximity of Portugal's formal integration into the EEC/EU structures, "views that stem from the complementary perspectives of an analysis from the inside out and from the outside in, thus illuminating governmental decisions, to fit more appropriately national and international realities" and, in this regard, "how not to follow (...) the OECD's recommendation that the obvious priority, I quote, is to establish a system of technical education, practically from scratch" ${ }^{35}$

Among the factors which explain the creation of technical education, in addition to unemployment, which hit more than 500,000 young people aged $15-19$, were noted the "response to the pressure of a set of social, economic and political factors that led to the adoption of a model and its rapid implementation on the ground", 36 as well as the adoption of a demanding and critical stance on part of the Portuguese employers:

For them, the State should 'provide' the skilled workers that various sectors of economic activity lack. The problem is rarely seen as a necessity of the Portuguese economy in the face of which the entrepreneurs themselves must mobilise by acting together. The school institution is insistently required to train qualified technicians that the economic reconversion requires. ${ }^{37}$

Similarly, the preamble to the legal Act framing the creation of technical and professional courses at the level of complementary education confirms the purpose of preparing young people for employment:

The Government's education policy gives priority to the institutionalisation of a vocational education structure in secondary education through an emergency plan for the reorganisation of technical education which will meet the needs of the country in labour-skilled workers as well as the pursuit of an employment policy for young people. ${ }^{38}$

The structure and design of the courses took up the logic of the professions over that of professional sectors, to the detriment of a more sectoral and broader approach as envisioned in Veiga Simão' reform. In the academic year of 1983-1984, the offer of technical-professional courses was made available in 42 schools, with a registered enrolment of 225 students. ${ }^{39}$

\footnotetext{
${ }^{33}$ Ministério da Educação, Relatório e Documentos do Encontro para Apresentação Pública do Exame da Política Educativa da OCDE, 5 (complete reference at footnote 10).

${ }^{34}$ Idem, ibidem, 32.

${ }^{35}$ Idem, ibidem, 15-7.

${ }^{36}$ Joaquim Azevedo, "O ensino técnico-profissional e o seu desenvolvimento futuro [Technical and vocational education and its future development]," in Sistema Educativo e Formação Profissional. Relatório de Seminário, ed. Ministério da Educação, 65-76 (Lisbon, 1987), 67.

${ }^{37}$ Idem, ibidem, 70.

${ }^{38}$ In Diário da República n. ${ }^{\circ}$ 243/1983, 10 Suplemento, Série I, de 21/10/1983, 3667.

${ }^{39}$ A number which rose to 1,497 in 1984/1985, 4,506 in 1985/1986, 8,615 in 1986/1987 and 13,615 in 1987/1988 (Joaquim Azevedo, 1991). Nevertheless, enrolment was relatively low compared to the total number of secondary school students. In 1983 and 1988, the students who attended the general courses accounted for, respectively, 83.8\% and $78.7 \%$ of the total of students (PORDATA website, 28 June 2019).
} 
The selection of priorities is particularly relevant when there are ambitious plans that may be frustrated by shortage of resources. Herein lies the first dilemma in connection with the country's duality. Great emphasis is now laid on the development of the inner country rather than on the expansion of already established industries. Could that imply a similar priority in terms of professional training? Bearing in mind the fact that regional development demands modest qualifications on part of individuals, requiring short training periods, possibly work-based, the priority should perhaps be given to the acquisition of specialised industrial qualifications. ${ }^{40}$

As highlighted by Krueger and Kumar, education systems strongly based on "skillspecific" knowledge, as opposed to "concept-based" knowledge, may shape a less flexible labour force and lead to a lower growth rate of the country in an era of rapid technological change. ${ }^{41}$ Additionally:

By raising and framing specific issues, the OECD affects the direction and objective of discussions on a specific topic. By defining how such problems should be seen or could be solved, the organization identifies and operationalizes common norms and meanings through best-selling publications that deal with common problems and typically imply future scenarios. With this capacity, international organizations like the OECD are able to influence the international and national debate on a policy issue. ${ }^{42}$

Lemos expressed the view that the impact of the report produced by the OECD was not, however, restricted to the dimension of technical and professional education, arguing that other issues addressed in the report, such as the organic reform of the Portuguese Ministry of Education, with the creation of Regional Education Directorates, the definition of the regime of school autonomy or the reorganisation of initial and in-service training of teachers, "have become the axes of intention of the Portuguese public education policies until the first decade of the twenty-first century, functioning as anchors of these policies for successive governments". ${ }^{43}$

By contrast, we argue that this position on the part of the OECD entirely corresponded to what the political power in the early 1980s wanted to hear. In a context still deeply marked by the education-democracy axis, prevalent at the time of the revolutionary crisis, the OECD report became the international document legitimising that "top priority", which meant the (re)creation of the technical-professional education, in an openly Fordist curricular framework. Despite having country-specific characteristics, that priority corresponded to a tendency also observed in other European countries, identified by several authors ${ }^{44}$ as new vocationalism. According to Moore, the characteristic that distinguishes and gives meaning to the pedagogy stems from a behavioural

\footnotetext{
${ }^{40}$ OCDE, Exame das Políticas Nacionais de Educação, 183-4.

${ }^{41}$ Dirk Krueger and Khrisna B. Kumar, "Skill-Specific rather than General Education: A reason for US-Europe Growth Differences?" Journal of Economic Growth 9, no. 2 (2004): 167-207.

${ }^{42}$ Martens and Jakobi, "Introduction: The OECD as an Actor International Politics," in Mechanisms of OCDE Governance. International Incentives for National Policy-Making, ed. Kerstin Martens and Anja Jakobi (New York: Oxford University Press, 2010), 10.

${ }^{43}$ Valter V. Lemos, "A influência da OCDE nas políticas públicas de educação em Portugal" (PhD Thesis, ISCTE-Instituto Universitário de Lisboa, Lisbon, 2014), 144, https://repositorio.iscte-iul.pt/bitstream/10071/8434/1/Tese\%20Valter\% 20Lemos\%20\%28\%2B\%20anexos\%20e\%20CV\%29.pdf (accessed 17 March 2020).

${ }^{44}$ See, e.g.: I. Bates, ed., Schooling for the Dole? The New Vocationalism (London: MacMillan, 1984); R. Dale, The State and Education Policy (Milton Keynes: Open University Press, 1989); G. Rees, "The New Vocationalism: Further Education and Local Labour Markets," Journal of Education Policy 3, no. 4 (1989): 227-44. DOI: https://doi.org/10.1080/ 0268093890040302.
} 
specialisation of the industry's needs, in what is perceived to be the skills demanded by the jobs. These skills are, still according to Moore, mere rhetoric aimed at working above all as a particular ideological representation. ${ }^{45}$

The notion underlying that orientation in the Portuguese case was that "the offer of human resources with adequate qualifications is essential for the economy's modernisation, and also that even in a situation of serious unemployment there are potential jobs vacant as a result of lack of specialised labour". 46 The state assumes the role of modernising actor, by granting the educational system's goals and functions related to technological change and economic modernisation, that is, by legitimising the economic role of the democratic school.

The trend toward a professional/vocational education is present in educational policies of many European countries where mass schooling has developed. However, the emergence of a discourse legitimizing the changes inherent in this policy acquires a specificity which varies according the characteristics of each one of them. Any analysis aiming at reconstructing the meaning of the debate produced in the 1980s around the restructure of the Portuguese educational system will face a diverse collection of texts appealing to the so-called 'modernization needs'. This appeal to modernization is, in fact, the dominant element in the discourse on the educational system, and constitutes the slogan used to highlight the need to bridge the gap between school and active life, without needing to explain what is meant by active life or what is the nature of the relationships concerned. ${ }^{47}$

In an ex-post evaluation carried out between 1986 and 1987, ${ }^{48}$ a number of aspects were pointed out as major weaknesses in Seabra's reform: low demand, with a significant part of the available supply without candidates (especially in traditional workers' areas such as mechanics or construction), accompanying the tendency of young people to continue their studies, a heavy and inadequate curriculum, as well as poor articulation between schools, the Ministry and the economic fabric. ${ }^{49}$

The year of 1986 was marked by two important events. First, the formal integration into the EEC/EU structures that began in January. The integration of Portugal into the $\mathrm{EEC} / \mathrm{EU}$ enhanced the participation in projects, networks, and forms of transnational interaction favouring the affirmation of common languages and thought categories. These would constitute the core of the discourse on educational reform, which then acquired the status of structural reform. Moreover, it started being presented as the means par excellence that would enable the school system to face the challenges posed by the European integration and the creation of the single market, by giving a decisive contribution to the economic sphere through a rapid increase in the qualification of human resources.

\footnotetext{
${ }^{45}$ Robert Moore, "Education and the Ideology of Production," British Journal of Sociology of Education 8, no. 2 (2006): 22742.

${ }^{46}$ Stephen R. Stoer, Alain D. Stoleroff and José A. Correia, "O novo vocacionalismo na política educativa em Portugal e a reconstrução da lógica da acumulação [The new vocationalism in education policy in Portugal and the reconstruction of the logic of accumulation]," Revista Crítica de Ciências Sociais 29 (1990): 11.

${ }^{47}$ Idem, ibidem, 46-7.

${ }^{48}$ The evaluation, which consisted of an exhaustive effort of data collection and survey of the actors involved in the whole country (Estudo de Avaliação da Experiência do Ensino Técnico-Profissional em Portugal [Study of Evaluation of the Experience of Technical and Vocational Education in Portugal], 12 volumes, Porto, 1987 and 1988), was coordinated by Joaquim Azevedo, who in 1988 would take over the direction of GETAP, a topic to be discussed below.

${ }^{49}$ Joaquim Azevedo, Educação Tecnológica nos Anos 90 [Technological education in the 1990s] (Rio Tinto: Edições ASA, 1991).
} 
The tendency to view vocational qualification as an integral part of the objectives of educational policy is therefore intensified by the integration of Portugal into the EEC/EU. European education policies devised from Brussels were based on two perversions: the first one resulted from the overdetermination of education by the economic context and labour, as consequence, to a large extent, of having arrived at the educational policies from broadening the concept of professional training; the second one resulted from the semi-clandestineness experienced by the Community concerning education, due to the fact that its founding treaties did not include any intervention in this area. This circumstance prevented true debate and democratic control, and originated an intervention deeply based on the experts' logic and on criteria of narrow economic rationality.

The political discourse emphasises the need to "respond to this challenge, making it a true exogenous driver of the country's development". ${ }^{50}$ Beyond the pressure to qualify represented by the financing of the European Union, including the provision of large amounts of structural funds for initial and continuing vocational training activities, a new examination of Portugal's educational policy promoted by the OECD in 1987 contained as central recommendation the investment in the initial professional qualification of young people.

Second, it should also be noted that in the same year (1986), in October, the Comprehensive Law on the Education System (LBSE) was approved, establishing the general framework of the education system, consigning an extended consensus of the Portuguese society regarding education, and establishing the existence of vocationally oriented courses.

It was in this scenario that the landmark for vocational education in Portugal occurred later, in January 1989, through the creation of fifty professional/vocational schools, seen as the renascence of vocational education in Portugal, ${ }^{51}$ but now rethought as a socially regulated, extended and grounded form of vocationalism.

\section{Vocational schools: an educational innovation that travelled from the margin to the centre}

In November 1988, a new administrative body, the Gabinete de Educação Tecnológica, Artística e Professional (GETAP), was created within the Portuguese Ministry of Education tasked with coordinating the system of non-higher education in the area of technological, artistic and professional education. This body was responsible for launching the professional schools in 1989, and also the technology courses at secondary-school level in 1993.

Professional schools were created under a programme-contract regime with the State, and the signing of protocols ensured the collaboration of the various promoters. Youngsters who had completed their ninth year of schooling would have access to these new schools. The legal framework of these schools was revised in 1993, leading to a restrictive formulation of their scope; in other words, vocational schools were now

\footnotetext{
${ }^{50}$ António Teodoro, "Reforma educativa ou a legitimação do discurso sobre a prioridade educativa [Educational reform or the legitimation of the discourse on educational priority]," Educação, Sociedade \& Culturas 4 (1995): 49.

${ }^{51}$ Maria de Fátima Cerqueira and Alcina O. Martins, "A consolidação da educação e formação profissional na escola secundária nos últimos 50 anos em Portugal [The consolidation of vocational education and training in secondary schools in the last 50 years in Portugal]," Revista Lusófona de Educação 17 (2011): 123-45.
} 
defined as a new type of school, intended for the implementation of technical secondary education in private educational establishments, in a process of the promoters' own initiative in each region and economic sector. Moreover, they arose as an answer to concerns about the diversification of the post-compulsory education provision and thereby contributing to the construction of a more autonomous and innovative system, an alternative to traditional classroom instruction, and finally to the mobilisation of civil society and the anchoring of training in regional and local development and job-creation projects.

The initiative of the State was linked to the autonomous initiative of social institutions acting within the framework of either a Central Administration programme or a sociocommunity scheme. Thus, in the context of the exercise of a "joint regulation" or a "multi-regulation" process, Azevedo, who was the director of GETAP, highlighted the innovation involved in this policy initiative: investment in a new form of partnership between the government and civil society, able to mobilise the cooperation of many local stakeholders and thus promote/foster the education of the youngsters involved in the model of contract programmes. As Azevedo noted:

This anchoring or social and communal tying, more than any ideological discourse, represented the most important of the guarantees, not only of the subordination of professional education to the primacy of the human development of the young and to the local social development, as well as of its own survival, beyond political fluctuations and private interests. ${ }^{52}$

The "educational innovations" referred to by Azevedo, understood by us as extended and grounded vocationalism, were indeed part of a common international movement which has placed vocational learning into a multi-purpose framework to meet the needs of different youths and communities, as well as the skill needs of employers. ${ }^{53}$

\section{Final remarks}

In a previous article ${ }^{54}$ we have discussed how participating in the Mediterranean Regional Programme, designed and led by the OECD between 1960 and 1974, was important to integrate Portugal in the Western sphere of influence. After an interregnum, in which relations were favoured with UNESCO and the World Bank, the OECD's comeback to a dominant role in national education would take place at the beginning of the 1980s, as a result of Portugal's decision to apply for integration into the group of OECD countries participating in the programme examining national education policies.

The examination conducted by the OECD experts at the beginning of the 1980s would, in fact, focus on a single point: criticism of the fact that national policies had neglected young people's vocational training. Defending technical and professional education as a capital priority of the Portuguese educational policy, the OECD advised

\footnotetext{
${ }^{52}$ Joaquim Azevedo, "Ensino profissional em Portugal, 1989-2014: Viagem da periferia para o centro das políticas educativas [Professional education in Portugal, 1989-2014: A journey from the periphery to the centre of educational policies]," in 40 Anos de Políticas de Educação em Portugal, Vol. 1, ed. Maria de Lurdes Rodrigues (pp. 411-468) (Coimbra: Almedina, 2014), 424.

${ }^{53}$ Jeff Malley and Jack Keating, "Policy Influences on the Implementation of Vocational Education and Training in Australian Secondary Schools," Journal of Vocational Education and Training 52, no. 4 (2000): 627-65.

${ }^{54}$ António Teodoro, 2020 (reference at footnote 4).
} 
the rapid creation of professional courses targeted at individuals from the age of fourteen, adding, probably as a criticism of prior governmental options, proposed or supported by the World Bank, that furthering access to polytechnic institutes was not a priority. The report then produced by the OECD became the international document legitimising, as the national top priority, the (re)creation of the professional and technical-professional education, within an openly Fordist curricular framework, following a trend also observed in other European countries towards a new vocationalism.

A new examination of Portugal's educational policy promoted by the OECD in 1987 contained as central recommendation the investment in the initial professional qualification of young people. It should be also noted that one year previously the Comprehensive Law on the Education System (LBSE), which established the general framework of the education system, had been approved, forming an extended consensus of the Portuguese society regarding education, and establishing the existence of vocationally oriented courses. It was in this scenario that during the 1990s a school-based model of vocationalism emerged that encompassed economic, educational and social objectives. The model contained elements of a vocationalism that linked general and vocational learning, school, communities and employers, and proved fundamental for the definitive affirmation of vocational learning as an alternative modality to regular secondary education.

In short, this examination carried out by the OECD effectively paved the way for the renascence of professional education in Portugal, but now rethought and redefined as a socially regulated, extended and grounded form of vocationalism.

\section{Acknowledgements}

A special thanks to Isabel Canhoto, who made a remarkable revision of the text for its publication in English, and the two anonymous reviewers who presented relevant suggestions and commentaries.

\section{Disclosure statement}

No potential conflict of interest was reported by the author(s).

\section{Funding}

This work was supported by the Portuguese FCT - Fundação para a Ciência e a Tecnologia, I.P., under project PTDC/CED-EDG/30084/2017;Fundação para a Ciência e a Tecnologia [PTDC/ CED-EDG/30084/2017];

\section{Notes on contributors}

António Teodoro is Professor of Sociology of Education and Comparative Education at Lusofona University, in Lisbon, director of the Interdisciplinary Research Centre for Education and Development (CeiED), and editor of Revista Lusófona de Educação (Lusofona Journal of Education). He is founder and chair of the Portuguese Society of Comparative Education (SPCESEC), and member of the Executive Committee and chair of the Constitutional Standing Committee of the World Council of Comparative Education Societies (WCCES). Recent book: 
Contesting the Global Development of Sustainable and Inclusive Education. Education Reform and the Challenges of Neoliberal Globalization, New York and London, Routledge, 2020).

Teresa Teixeira Lopo is research fellow at the Interdisciplinary Research Centre for Education and Development (CeiED) of Lusofona University. She is a sociologist, has a Master and a DEA in Educational Sciences and is a PhD candidate in Education, with thesis completed at the School of Social Sciences and Humanities of NOVA University of Lisbon. She has worked in various research projects addressing the themes of policy and politics in education. She was an Adjunct Professor at the Lisbon School of Dance of the IPL-Polytechnic of Lisbon, from 2011 to 2017, where she taught History of Contemporary Education.

\section{ORCID}

António Teodoro (D) http://orcid.org/0000-0001-7819-0498

Teresa Teixeira Lopo (D) http://orcid.org/0000-0001-5483-1975 